\title{
FULFILLMENT OF EDUCATION RIGHTS IN THE BORDER AREAS OF INDONESIA AND MALAYSIA
}

\section{Endah Rantau Itasari}

Fakultas Hukum

Universitas Tanjungpura Pontianak

Email : itafira@yahoo.com

\begin{abstract}
The opening of access to education for all citizens is a conditio sine qua non value of freedom and justice. As long as there are citizens who cannot get access to education, even though at the most basic level, the state is the agency most responsible for this injustice. Without the guarantee of these basic needs, citizen participation in a democratic climate that allows for upward social movements to be far from expectations The elimination of discrimination should be done by providing the widest opportunity for every citizen to get an education, so that cheap schools, even free, will be created for all the people without exception. Therefore the government is required to be able to be fair by providing equal opportunities for every citizen to take education (formal) and be able to protect and guarantee the rights of citizens, especially for those who are financially incapable so that they can continue to receive proper education.
\end{abstract}

Keywords: education, human rights, border areas, Indonesia, Malaysia

\begin{abstract}
Abstrak
Terbukanya akses pendidikan bagi semua warga negara merupakan conditio sine qua non dihargainya nilai kebebasan dan keadilan. Selama masih ada warga negarayang tidak dapat memperoleh akses pendidikan, meski di tingkat paling dasar, negara merupakan instansi yang paling bertanggung jawab atas ketidakadilan ini. Tanpa dijaminnya kebutuhan dasar ini, partisipasi warga dalam iklim demokrasi yang memungkinkan terjadinya pergerakan sosial ke atas kian jauh dari harapanPenghapusan diskriminasi perlu kiranya dilakukan dengan memberi kesempatan yang seluas-luasnya kepada setiap warga negara untuk mengenyam pendidikan, sehingga sekolah murah, bahkan gratis, akan tercipta bagi segenap rakyatnya tanpa terkecuali. Oleh karenanya pemerintah dituntut untuk bisa berlaku adil dengan memberikan kesempatan yang sama bagi setiap warga negara untuk menempuh pendidikan (formal) dan mampu melindungi serta menjamin hak-hak warga negara terutama bagi mereka yang secara finansial tidak mampu supaya tetap bisa menempuh pendidikan yang layak.
\end{abstract}

Kata kunci : pendidikan, hak asasi manusia, wilayah perbatasan, Indonesia, Malaysia 


\section{Introduction}

The existence of the right to education has no doubt the truth at both national and international levels. ${ }^{1}$ Especially in Indonesia, the political dynamics of national law affect the implementation of the right to education originating from the 1945 Constitution of the Republic of Indonesia (the 1945 Constitution) and the main provisions of international human rights as in the Universal Declaration on Human Rights (UDHR) 1949, The International Covenant on Economic, Social and Cultural Rights (ICESCR) 1966 and at the Convention on The Rights of The Child 1989.

In the Preamble of the 1945 Constitution it was emphasized that one of the objectives of the establishment of the government of the State of Indonesia was "to educate the life of the nation". This objective is then manifested through Article 28C Paragraph (1) and Article 31 of the 1945 Constitution and further elaborated in various laws and regulations including Law No. 20 of 2003 concerning the National Education System as lex specialis. In connection with the ICESCR, Indonesia has ratified the covenant on 30 September 2005 through Law Number 11 of 2005 concerning Ratification of the International Covenant on Economic, Social and Cultural Rights ${ }^{2}$. In the ICESCR itself the right to education is specifically regulated in Article 13 and Article 14.

The nature of the right to education at the level of basic education, as confirmed in the ICESCR, is a certain condition that must be created by the ratifying state $^{3}$. The substance of education and managerial aspects of administering education is a basic element in Article 13 of the ICESCR for countries to provide basic education for everyone. Aspects of availability and ease of educational facilities and infrastructure, and aspects of acceptance and adjustment are legal segments (indicators) that must be gradually conditioned by the state to be fulfilled at any time and their fulfillment in education, especially primary and secondary education. ${ }^{4}$

Indonesia as a party to the ICESCR is bound to implement these provisions based on the international obligations contained therein ${ }^{5}$. The Bonanza Perwira Taihitu provides an argumentative framework that the politics of Indonesian national law towards the implementation of the above international human rights law provisions between 1990 and the end of 2005 is more likely to be a national

Klaus Dieter Beiter, The Protection of the Right to Education by International Law, Martinus Nijhoff Publisher, 2005, hlm. 1-10.

2 Kovenan Internasional tentang Hak-Hak Ekonomi, Sosial dan Budaya yang termuat dalam Lembaran Negara Republik Indonesia Tahun 2005 Nomor 118, Tambahan Lembaran Negara Republik Indonesia Nomor 4557.

3 M. Freeman, “The Limits of Children's Rights, dalam The Ideologies of Children's Rights, 1992, hlm. 30-31.

4 Katarina Tomasevski, "Indicators" dalam Asbjorn Eide (et.al), 1995, Economic, Social and Cultural Rights, A Textbook, hlm. 390.

5 M Santos Pais, “A Human Rights Conceptual Framework for Children's Rights” dalam UNICEF Innovative Essay No.9, hal. 5. 
image in an international forum ${ }^{6}$. Thus, the basic obligations in these provisions are implemented to attract more foreign sympathy rather than their use for national interests. $^{7}$

It is interesting to study whether the nature and purpose of national legal politics in Indonesia towards the fulfillment of the right to education, especially primary and secondary education after the amendment to the 1945 Constitution. Is the motivation for animating ICESCR a meaningful juridical study. The juridical study was related to 11 clusters of findings regarding the issue of fulfilling the right to education by the Ministry of Education and Culture of the Republic of Indonesia (Ministry of Education and Culture of the Republic of Indonesia) ${ }^{8}$. One cluster of these problems is the issue of fulfilling children's rights to primary and secondary education in Indonesia's border areas with other regions such as Malaysia, Papua New Guinea (PNG) and the East Timor Democratic Republic (RDTL) ${ }^{9}$.

\section{Literature Review}

\subsection{Human Rights as Fundamental and Universal Rights}

The concept of Human Rights (HAM) includes three main elements for human existence both as individual beings and social beings, namely human integrity, freedom and equality. ${ }^{10}$ These three elements are conceptualized into understandings and understanding of what human rights are.

Understanding of this understanding becomes clear when recognition of these rights is given and is seen as a human process of humanization by other parties in a vertical context (individual with state) and horizontal (between individuals) both de facto and de jure. Thus, human rights values are fundamental and universal in the presence of recognition, protection and promotion of integrity, freedom and human equality in the main international human rights instruments, both at the international, regional and national levels. Even though its values are universal, human rights can be distinguished into several normative academic groupings namely, first, personal rights or "personal rights". Second, economic rights or the right to own something ("property rights"). Third, the right to get equal and equal treatment in law and government or "right of legal equality". Fourth, political rights or "political rights". Fifth, social and cultural human rights or "social and cultural rights", such as obtaining and choosing education, develop the preferred culture. Sixth, the right to litigation and its protection or "procedural rights". Understanding and understanding of human rights in terms of these substances becomes complicated and complex based on developments, existing realities and the complexity of other determinant factors.

\footnotetext{
6 Bonanza Perwira Taihitu, "Penaatan Indonesia Pada Standar-Standar Hak Asasi Manusia Internasional”, Thesis Fisipol UI, Universitas Indonesia, 2003, hlm. 134-135.

$7 \quad$ Ibid, hlm. 105.

$8 \quad$ Biro Hukum dan Organisasi Setjen Kemdikbud, "Monitoring dan Evaluasi Pemenuhan Hak Atas Pendidikan di Indonesia Tahun 2011", Biro Hukum dan Organisasi Setjen Kemdikbud, 2012, hlm. 10-17.

$9 \quad$ Ibid, hlm. 25-30.

10 Eide, Asbjorn, Catarina Krause, Allan Rosas, 1995, Economic, Social and Cultural Rights, A Textbook, Martinus Nijhoff, Dordrecht, hlm. 21.
} 
The concept and values of human rights change and over time both through evolutionary and revolutionary processes from normative forces into the process of social and political change in the entire order of human life. ${ }^{11}$ Thus, understanding and understanding of the meaning of human rights in terms of substance must be returned to the basic concept of why human rights exist. Human rights exist and arise because these basic rights are very basic or fundamental in the sense that their implementation is absolutely necessary so that humans can develop according to their talents, ideals, and dignity as human beings regardless of differences that cause discrimination based on nation, race, religion and gender. The principles of understanding human rights must be used as the main foundation so that the understanding and understanding of human rights from the substantive aspect becomes applicable. These principles are the application of the concept of the indivisibility and the interdependence of the values of human rights themselves. ${ }^{12}$

According to the ontology, human rights are rights owned by humans that are obtained and carried along with their birth or presence in people's lives because they have a privilege that opens the possibility for them to be treated according to those features. ${ }^{13}$ With a simpler understanding, human rights are the rights of someone who if the rights are taken from him will result in the person becoming no longer human. ${ }^{14}$

Human rights, as understood in the human rights documents that emerged in the twentieth century such as the Universal Declaration of Human Rights (UDHR), have a number of prominent features, namely: ${ }^{15}$ First, so that we do not lose the already firm ideas, human rights are rights. The meaning of this term is unclear, but at least the word indicates that it is certain norms that have high priority which is mandatory. Second, these rights are considered universal, which are owned by humans solely because they are human. This view implies that characteristics such as race, gender, religion, social position, and citizenship are not relevant to question whether a person has or does not have human rights. This also implies that these rights can be applied throughout the world. One special feature of human rights that is in force now is that it is an international right. Compliance with similar rights has been seen as an object of legitimate attention and international action.

Third, human rights are considered to exist by themselves, and do not depend on their recognition and application in customary systems or legal systems in certain countries. This right may indeed not be an effective right until it is carried out according to law, but that right exists as a standard of argument and criticism that does not depend on the application of the law. Fourth, human rights are seen as important norms. Although not entirely absolute and without exception, human

11 Taihitu, Bonanza Perwira,2003, Penaatan Indonesia pada Standar-Standar HAM Internasional Dalam Kurun Waktu 1991-2002, Thesis pada Fakultas Ilmu Sosial dan Politik Departemen Ilmu Hubungan Internasional, Pasca Sarjana Universitas Indonesia, hlm. 38.

12 UNICEF, 1998, A Human Rights Approach to UNICEF Programming for Children and Women : What It is and Some Changes It Will Bring.

13 Theo Huijbers, 1990, Filsafat Hukum, Penerbit Kanisius, Yogyakarta, hlm. 96.

14 United Nations, 1998, Human Rights, Questions and Anwers, United Nations Department of Public Information, New York, hlm. 4

15 Nickel, James W., 1987, Making Sense of Human Rights: Philosophical Reflection on the Universal Declaration of the Human Rights, The Regents of the University of California. 
rights have a strong position as normative considerations to be applied in conflicts with national norms that are contradictory, and to justify international actions taken for human rights. The rights outlined in the Declaration are not arranged according to priorities; its relative weight is not called. It is not stated that some of them are absolute.

Thus the human rights described by the Declaration are something philosophers call prima facie rights. Fifth, these rights imply obligations for individuals and the government. The existence of this obligation, as well as the rights associated with it, is deemed not to depend on the acceptance, recognition or application of it. Governments and people everywhere are obliged not to violate someone's rights, even though the government of the person may also have the primary responsibility to take positive steps to protect and uphold the rights of that person. set minimum standards for proper community and state practice. Not all problems born of cruelty or selfishness and ignorance are human rights problems. For example, a government that fails to provide national parks for its people can indeed be criticized as being incompetent or not paying enough attention to opportunities for recreation, but this will never be a human rights issue.

\subsection{Education in Human Rights}

Education is a human right and has gained status as one of the fundamental human rights. ${ }^{16}$ The right to education is part of economic, social and cultural rights, whose fulfillment is part of the state's obligations to its people. ${ }^{17}$ In principle, everyone has the same right to take part in education and enjoy the results at all levels of education without discrimination. ${ }^{18}$ The government must put education as a right and disseminate understanding of it (dissemination), monitor and evaluate its implementation (monitoring and evaluation), and implement policies based on these two previous steps in real (adjudication). ${ }^{19}$

On the other hand, Robert McCorquodale reinforces the juridical assumption that the right to education in the international legal system has a compelling nature because the subjects of international law, especially international organizations, consistently place their fulfillment obligations imperatively for their members. The basic argument is that international organizations have an international obligation to protect human rights, specifically the fulfillment of the right to education based on 3 (three) legal arguments, namely: (1). International organizations may not act in contravention of the legal obligations of their members to their obligations on the instruments of protection of human rights law they receive, especially the fulfillment of the right to education; (2). International organizations are bound by

\footnotetext{
16 Pasal 26 Deklarasi Universal Hak Asasi Manusia 1948 dan Pasal 13 Kovenan Hak Ekonomi Sosial dan Budaya 1966.

17 Yosep Adi Prasetyo, "Hak Ekosob dan Kewajiban Negara", Pemerkuatan Hak Asasi Manusia Untuk Hakim Seluruh Indonesia, Holiday Resort Lombok, 28-31 Mei 2012, hlm. 2-6 dan Beitz, Charles, The Idea of Human Rights, Oxford University Press, 2009, hlm. 7-8

18 Pasal 3 Undang-Undang Nomor 20 tahun 2003 tentang Sistem Pendidikan Nasional.

19 Lihat Keppres Nomor 40 Tahun 2004 Tentang Rencana Nasional HAM RI dan Peraturan Presiden Nomor 23 tahun 2011 Tentang Aksi Nasional HAM tahun 2010-2015.
} 
international customary law concerning the protection of human rights as well as in the state and individuals in fulfilling the right to education which has become the main goal of its establishment; and (3). The obligation of the human rights protection law has developed directly into international organizations. ${ }^{20}$ As a recent example of the status of the right to education in the international legal system, the ASEAN Declaration of Human Rights takes these three legal arguments as rationality and legal facts to establish norms and mechanisms for the formation of rights to development. ${ }^{21}$

In line with the two legal arguments mentioned above, the Committee on Economic, Social and Cultural Rights states that: "State Parties should ensure that their actions as members of international organizatioions take due account of their rights to education. Accordingly, State parties that are members of international financial institutions, notably the International Monetary Fund, the World Bank, and regional development banks, should take steps to ensure that the right to education is taken into account in their lending policies, credit agreements and other international measures". ${ }^{22}$ Easily, international organizations are bound to the obligation to fulfill and protect the right to education in carrying out their functions. ${ }^{23}$ In addition, international jurisprudence also reinforces the aforementioned argument that international organizations have the obligation to fulfill and protect human rights directly based on the application of international customary law as a tribute to the UN Charter. ${ }^{24}$

20 Robert McCorquodale, International Organizations and International Human Rights Law: One Giant Leap for Humankind, in Kaiyan Homi Kaikobad and Michael Bohlander, International and Power Perspective on Legal Order and Justice, Martinus Nijhoff Publishers, 2009, hlm. 154-156.

21 Deklarasi HAM ASEAN ini ditandatangani oleh 10 kepala negara anggota ASEAN pada tanggal 18 November 20120 oleh Haji Hassanal Bolkiah, Samdech Akka Moha Sena Padei Techo Hun Sen, Susilo Bambang Yudhoyono, Thongsing Thammavong, Dato Sri Mohd Najib Tun Abdul Razak, U Thein Sein, Benigno S Aquino III, Lee Hsien Loong, Yingluck Shinawarta, Nguyen Tan Dung yang mengadopsi 9 prinsip dasar HAM, 15 hak sipil dan politik, 9 jenis hak ekonomi, sosial dan budaya, hak atas pembangunan, hak atas perdamaian dan ditutup dengan kerjasama regional dan internasional dalam hal pemajuan HAM dalam Deklarasi tersebut. Lihat Phnom Penh Statement on the Adoption of the ASEAN Human Rights Declaration (AHRD), 18 November 2012; Tommy Koh, op.cit, no. 1, hlm. 18; Heppy Ratna, AICHR dan Penguatan Perlindungan HAM di ASEAN, http://news.antara.co.id/berita/1256362459/aichr-dan-penguatan-perlindungan-ham-diasean, 2009; dan Human Rights Committee, General Comment 3, Article 2, para 1, Implementation at the national level (Thirteenth session, 1981), Compilation of General Comments and General Recommendations Adopted by Human Rights Treaty Bodies, UN Doc. HRI/GEN/1/Rev.1 at 14 (1994), University of Minnesota Human Rights Library, http://www1.umn.edu/humanrts-/gencomm/hrcom13.htm.

22 Committe on Economic, Social and Cultural Rights, General Comments 15: The Rights To Water", UN Doc. E/C.12/2002/II, 2002, para. 36.

23 Coomans and Kaminga (eds), Extraterritorial Application of Human Rights Treaties, Antwerp, 2004, hlm. 214 dan Reinisch, "Securing the Accountability of International Organizations", 7 Global Governance, 2001, hlm. 131-135.

24 Blokker and Schemers, International Institutional Law, Fourth Edition, Leiden, 2003, hlm. 1002-1003. 


\section{Discussion and Results of Research}

West Kalimantan Province (West Kalimantan) has been used as a study review and initiation of increasing the fulfillment of the right to education by the Ministry of Education and Culture since 2009, especially in the border region with Malaysia. The lack of facilities and infrastructure, the low desire to go to school, the reluctance of education actors to carry out the duties and functions of educators and the low allocation of education funds have led to underdevelopment and inequality in obtaining access to education in these border regions. ${ }^{25}$

Most of the West Kalimantan border region with Sarawak, Malaysia is also included as a Disadvantaged, Leading and Outermost Region (D3T) which is currently a development priority in accordance with Nawacita's vision of President Joko Widodo. In 2015, 122 districts were designated as disadvantaged areas and 43 leading and outermost areas based on Letter No. 2421 / Dt.7.2 / 04/2015 April 21, 2015 by the Ministry of National Development Planning / National Development Planning Agency (Kemen PPN / BAPPENAS). In the list Sambas Regency, Bengkayang Regency, Sintang Regency and Kapuas Hulu Regency are included in the D3T.

To overcome the fulfillment of the right to education in the D3T region, various policies have actually been carried out by the government, one of which is the Undergraduate Teaching Program in the Leading, Outermost and Disadvantaged Regions (SM-3T) to overcome the shortage of teachers in the border area.

The SM-3T movement is the solution to the problem of the lack of educators in the D3T. From the movement, graduates of education S1 can transfer their knowledge to people who really need it. In this movement the educators were sent to the D3T area outside Java, especially in the eastern part of Indonesia such as the interior of Kalimantan, Sulawesi, Papua and so on.

The benefit of the movement is in addition to assisting the lack of educators in the D3T as well as preparing strong, independent and competent educators and having extensive knowledge about the conditions of education in Indonesia so that the prospective educators can use their knowledge consciously to build and educate nation. In addition, the existence of the movement is also useful to create educators who have a high social life because with the experience of following the movement prospective educators share the lives of people in the D3T so that their souls are moved to improve their lives through education.

However, the SMT 3T program also faced several obstacles, especially the lack of interest of students and educational scholars to join the program. For example, at the Indonesian Education University (UPI), which is one of the 17 tertiary institutions that hold SM-3T programs, in the first wave only 66 participants

25 Marzuki, "Permasalahan Pemenuhan Hak Atas Pendidikan di Wilayah Provinsi Kalimantan Barat", Makalah Forum Grup Discussion, Pemetaan Permasalahan Pendidikan Di Wilayah Perbatasan Negara, Setjen Kemdikbud, Hotel Park Jakarta, 23-24 November 2011. 
were sent and in the second wave the number dropped to 64 participants. Even though UPI got a quota of 300 participants. ${ }^{26}$

With these conditions, it is also relevant to review regulations, policies and programs and budget allocations set by the government, both central and regional, in the education sector to meet availability, accessability, acceptability and adjustment principles (adaptability) based on actual conditions, especially in the border areas included in the D3T.

These problems turned out to have similarities with the problems in Papua, especially in the border areas with Papua New Guinea (PNG) and in East Nusa Tenggara, especially in the Atambua region which borders the Democratic Republic of East Timor (RDTL). ${ }^{27}$ However, the borders of West Kalimantan and Malaysia are different from the borders with PNG and RDTL because Malaysia has a level of welfare and progress that is above Indonesia, including in the education sector. This has more or less influenced the condition of education in the border region of West Kalimantan with Sarawak, Malaysia, where the phenomenon of children of Indonesian citizens who participate in enjoying Malaysian education facilities can be found in several regions. This phenomenon is a reflection of how the limited presence of countries in the border region is then addressed by the border community by seeking fulfillment of basic services including the right to education to neighboring countries.

At the normative level, to ensure the fulfillment of the community's need for proper education, the state has an obligation to ensure the provision of an adequate education system and curriculum, provision of scholarships, provision of adequate facilities and infrastructure, improving the quality of educators and teachers in universities. ${ }^{28}$ According to the obligations contained in the ICESCR, the education system established by the government must be able to reach all citizens, be freely accessible without discrimination and be economically and psychologically acceptable, and can adapt to the times. ${ }^{29}$

Decision of the Constitutional Court in Case Number 012 / PUU-III / 2005 Concerning Testing of Law No. 36 of 2004 Concerning the National Budget on the recognition, promotion and protection of human rights in the field of education reinforces the long-standing debate that does not end on the state's obligation to fulfill economic, social and cultural rights as contained in the Covenant. ${ }^{30}$ Issues

26 Sisca Fitriyani, 2013, "Persepsi Mahasiswa Program Kependidikan Universitas Pendidikan Indonesia Terhadap Program Sarjana Mendidik di Daerah Terdepan, Terluar dan Tertinggal", dalam repository.upi.edu/436/4/S_GEO_0900185_CHAPTER\%201.pdf, diakses tanggal 12 September 2017.

27 Biro Hukum, op.cit, no. 8, hlm. 21.

28 Committee on Economic, Social and Cultural Rights General Comment 13, The Right to Education (Art. 13), 08/12/99, E/C.12/1999/10, CESCR, 8 December 1999, para 1; pernyataan ini didukung oleh the World Bank in Crying Out for Change, World Bank in three volumes (2002), hlm. 235.

29 Colin Wringe, 2006, Moral Education: Beyond the Teaching Rights and Wrong, Springer, hlm. 51-52.

30 Heribertus Jaka Triyana, "Implikasi Hukum Ratifikasi Kovenan Hak Ekonomi Sosial dan Budaya Terhadap Pemenuhan Hak Atas Pendidikan di Indonesia", Jurnal Hukum dan HAM, Vol. 4 Nomor 1, Juni 2006, Juni 2006, ISSN 1693-4512, hlm. 27-30. 
such as access to education, reduction of drop-out students, strengthening and support for existing and general basic education institutions and handling access to education in remote areas have not been addressed. ${ }^{31}$

In the province of West Kalimantan, geographical constraints with disparities and natural contours in the form of forests and hills have made access to education less so that affordability is low, especially in areas directly adjacent to Malaysia such as Entikong and Sambas. ${ }^{32}$ Although at several levels it appears that there are efforts by the Central Government and the Regional Government of West Kalimantan Province to deal with these issues, however, the handling steps still have not focused on both the quality and quantity of facilities and infrastructure. ${ }^{33}$

The government is still not serious about addressing the issue of access to education in West Kalimantan, West Kalimantan is a province that consists mainly of waters. Then access between regions in West Kalimantan mostly uses river transportation. Therefore, the government must be able to maximize transportation in West Kalimantan such as bridges, docks, and other supporting infrastructure. The point is the government must pay special attention to educational institutions domiciled in areas that have limited access to education. The best solution is to expand access to education and equal distribution of education services in both remote and urban areas.

The quality of education in West Kalimantan is still relatively low. This is evidenced by the output out of production in West Kalimantan, which has not yet shown the level of educational success. West Kalimantan annually employs thousands of new scholars, but has not yet had an impact on improving the quality of education in Indonesia. In addition, West Kalimantan has not been able to compete optimally both at national and international levels. The best solution is that the government must always strive to improve the quality of education and the competitiveness of graduates in West Kalimantan.

Tabel 1

Menurut Pendidikan Tertinggi yang Ditamatkan, Februari 2013-2015

\begin{tabular}{llll}
\hline \hline $\begin{array}{l}\text { Pendidikan Tertinggi yang } \\
\text { Ditamatkan }\end{array}$ & $\mathbf{2 0 1 3}$ & $\mathbf{2 0 1 4}$ & $\mathbf{2 0 1 5}$ \\
\cline { 2 - 4 }$(1)$ & Februari & Februari & Februari \\
\hline SD Ke Bawah & $(2)$ & $(3)$ & $(4)$ \\
Sekolah Menengah Pertama & 1.364 & 1.352 & 1.189 \\
Sekolah Menengah Atas & 354 & 364 & 375 \\
Sekolah Menengah Kejuruan & 306 & 320 & 375 \\
& 97 & 102 & 140
\end{tabular}

Ibid.

Marzuki, op. cit, hlm. 6-7.

Ibid. 


\begin{tabular}{llll} 
Diploma I/II/III & 52 & 70 & 58 \\
Universitas & 103 & 101 & 121 \\
\hline Jumlah & $\mathbf{2 . 2 7 6}$ & $\mathbf{2 . 3 0 9}$ & $\mathbf{2 . 2 5 7}$ \\
\hline \hline
\end{tabular}

Sumber : BPS Provensi Kalimantan Barat, 2015.

Based on the table above stated that in West Kalimantan the highest education completed through data from February 2013 to 2015 showed a positive thing. However, with such results education in West Kalimantan still has problems that are immediately resolved.

The author still feels awkward with the management of teaching staff in West Kalimantan. This is evidenced by the equal distribution of teaching staff. Education in West Kalimantan Province is still far behind compared to other provinces in Indonesia. This is partly due to the inadequate number of educators in West Kalimantan. West Kalimantan still needs a lot of teaching staff, so that the number of educators is balanced with the number of educational institutions, population and area of West Kalimantan.

In addition, the dynamics of local politics with the implementation of decentralization policies in the form of delegating the authority to organize education from the Central Government to Regional Governments in response to equity and the effectiveness of the implementation of education do not automatically fulfill the right to basic and secondary education in the Malaysian border region in West Kalimantan. ${ }^{34}$ On the contrary, this delegation of authority actually results in the withdrawal of the quality of education because not all district governments have the same capability, both in terms of personnel capacity and even budgeting ${ }^{35}$. As a result, the disparity between districts became apparent and became a daily sight. More specifically, there are many reports of collapsing school buildings and school facilities that are far from the need to support the teaching and learning process, including the lack of permanent teachers that every educational institution must have. ${ }^{36}$

At the level of legislation, although there is already Law 20 of 2003 concerning the National Education System (Law on National Education System), at the regional level both Province and Regency / City in West Kalimantan there are no regional regulations that specifically regulate education issues. This is a consequence of the Regional Government law which emphasizes that education affairs are still a matter of the central government. Thus the regions do not regulate this further at the level of regional legislation.

With the current government policy that wants to start development from the border region and the outermost region, the conditions for fulfilling the right to education for the people in the border region should be a priority. Thus a study is

$\begin{array}{ll}34 & \text { Ibid, hlm. } 13 . \\ 35 & \text { Ibid. } \\ 36 & \text { Ibid. }\end{array}$


needed to get a picture of the politics of law and state policies in fulfilling the right to basic and secondary education for people on the border of West Kalimantan with Sarawak. Analysis of the situation and needs for the fulfillment of the right to primary and secondary education in the border areas of West Kalimantan Province needs to be carried out thoroughly towards policies, programs, activities and funding in fulfilling the right to education.

The implementation of these indicators will produce acceptable accountability and legitimacy especially in the implementation of international legal instruments that have been ratified by Indonesia. Theoretically practical, the legal indicators of implementation above can be measured through systematization of legal culture; legal structure (legal structure) and legal substance (legal substance) towards efforts to fulfill the right to education. The force of enforceability of the law will obtain legal, social and political justification so that this enforcement can be used as a reference for fulfilling the right to primary and secondary education in other countries' border areas, namely in Papua and in NTT.

\section{Conclusion}

The opening of access to education for all citizens is a conditio sine qua non value of freedom and justice. As long as there are citizens who cannot get access to education, even though at the most basic level, the state is the agency most responsible for this injustice. Without the guarantee of these basic needs, citizen participation in a democratic climate that allows for the occurrence of upward social movements is far from expectations. The poor will get poorer, the helpless will be more deceived. In a democratic society, politics is an expression of public trust, in the form of a mandate to bring prosperity to its citizens, including improving the quality of education and strengthening civil society (opening up equal opportunities for every citizen to be politically active). Without this effort, politics turns into a vehicle for mastering natural and social resources for the benefit of a handful of people. Therefore, access to education for all citizens is a basic priority because equality is guaranteed with it. Equality in attaining education enables each citizen to live up to his freedom so that they are able to actively participate in a democratic life that increasingly confirms their dignity as humans.

In connection with the above, the elimination of discrimination should be done by providing the widest opportunity for every citizen to get an education, so that cheap, even free schools, will be created for all of their people without exception. Therefore the government is required to be able to be fair by providing equal opportunities for every citizen to take education (formal) and be able to protect and guarantee the rights of citizens, especially for those who are financially incapable so that they can continue to receive proper education.

\section{References}

Beitz, Charles, The Idea of Human Rights, Oxford University Press, 2009. 
Biro Hukum dan Organisasi Setjen Kemdikbud, "Monitoring dan Evaluasi Pemenuhan Hak Atas Pendidikan di Indonesia Tahun 2011", Biro Hukum dan Organisasi Setjen Kemdikbud, 2012.

Blokker and Schemers, International Institutional Law, Fourth Edition, Leiden, 2003

Bonanza Perwira Taihitu, "Penaatan Indonesia Pada Standar-Standar Hak Asasi Manusia Internasional", Thesis Fisipol UI, Universitas Indonesia, 2003.

Colin Wringe, 2006, Moral Education: Beyond the Teaching Rights and Wrong, Springer,

Committe on Economic, Social and Cultural Rights, General Comments 15: The Rights To Water", UN Doc. E/C.12/2002/II, 2002, para. 36.

Committee on Economic, Social and Cultural Rights General Comment 13, The Right to Education (Art. 13), 08/12/99, E/C.12/1999/10, CESCR, 8 December 1999, para 1; pernyataan ini didukung oleh the World Bank in Crying Outfor Change, World Bank in three volumes (2002).

Coomans and Kaminga (eds), Extraterritorial Application of Human Rights Treaties, Antwerp, 2004, hlm. 214 dan Reinisch, "Securing the Accountability of International Organizations", 7 Global Governance, 2001.

Eide, Asbjorn, Catarina Krause, Allan Rosas, 1995, Economic, Social and Cultural Rights, A Textbook, Martinus Nijhoff, Dordrecht.

Heribertus Jaka Triyana, "Implikasi Hukum Ratifikasi Kovenan Hak Ekonomi Sosial dan Budaya Terhadap Pemenuhan Hak Atas Pendidikan di Indonesia", Jurnal Hukum dan HAM, Vol. 4 Nomor 1, Juni 2006, Juni 2006, ISSN 1693-4512.

Katarina Tomasevski, "Indicators" dalam Asbjorn Eide (et.al), 1995, Economic, Social and Cultural Rights, A Textbook.

Keppres Nomor 40 Tahun 2004 Tentang Rencana Nasional HAM RI dan Peraturan Presiden Nomor 23 tahun 2011 Tentang Aksi Nasional HAM tahun 20102015.

Klaus Dieter Beiter, The Protection of the Right to Education by International Law, Martinus Nijhoff Publisher, 2005.

Kovenan Hak Ekonomi Sosial dan Budaya 1966.

Kovenan Internasional tentang Hak-Hak Ekonomi, Sosial dan Budaya yang termuat dalam Lembaran Negara Republik Indonesia Tahun 2005 Nomor 118, Tambahan Lembaran Negara Republik Indonesia Nomor 4557.

M Santos Pais, "A Human Rights Conceptual Framework for Children's Rights" dalam UNICEF Innovative Essay No.9, hal. 5.

M. Freeman, “The Limits of Children's Rights, dalam The Ideologies of Children's Rights, 1992.

Marzuki, "Permasalahan Pemenuhan Hak Atas Pendidikan di Wilayah Provinsi Kalimantan Barat", Makalah Forum Grup Discussion, Pemetaan Permasalahan Pendidikan Di Wilayah Perbatasan Negara, Setjen Kemdikbud, Hotel Park Jakarta, 23-24 November 2011.

Nickel, James W., 1987, Making Sense of Human Rights: Philosophical Reflection on the Universal Declaration of the Human Rights, The Regents of the University of California. 
Phnom Penh Statement on the Adoption of the ASEAN Human Rights Declaration (AHRD), 18 November 2012; Tommy Koh, op.cit, no. 1, hlm. 18; Heppy Ratna, AICHR dan Penguatan Perlindungan HAM di ASEAN, http://news.antara.co.id/berita/1256362459/aichr-dan-penguatan-

perlindungan-ham-di-asean, 2009; dan Human Rights Committee, General Comment 3, Article 2, para 1, Implementation at the national level (Thirteenth session, 1981), Compilation of General Comments and General Recommendations Adopted by Human Rights Treaty Bodies, UN Doc. HRI/GEN/1/Rev.1 at 14 (1994), University of Minnesota Human Rights Library, http://www1.umn.edu/humanrts-/gencomm/hrcom13.htm.

Robert McCorquodale, International Organizations and International Human Rights Law: One Giant Leap for Humankind, in Kaiyan Homi Kaikobad and Michael Bohlander, International and Power Perspective on Legal Order and Justice, Martinus Nijhoff Publishers, 2009.

Sisca Fitriyani, 2013, "Persepsi Mahasiswa Program Kependidikan Universitas Pendidikan Indonesia Terhadap Program Sarjana Mendidik di Daerah Terdepan, Terluar dan Tertinggal", dalam repository.upi.edu/436/4/S_GEO_0900185_CHAPTER\%201.pdf, diakses tanggal 12 September 2017.

Taihitu, Bonanza Perwira,2003, Penaatan Indonesia pada Standar-Standar HAM Internasional Dalam Kurun Waktu 1991-2002, Thesis pada Fakultas Ilmu Sosial dan Politik Departemen Ilmu Hubungan Internasional, Pasca Sarjana Universitas Indonesia, hlm. 38.

Theo Huijbers, 1990, Filsafat Hukum, Penerbit Kanisius, Yogyakarta.

Undang-Undang Nomor 20 tahun 2003 tentang Sistem Pendidikan Nasional.

UNICEF, 1998, A Human Rights Approach to UNICEF Programming for Children and Women : What It is and Some Changes It Will Bring.

United Nations, 1998, Human Rights, Questions and Anwers, United Nations Department of Public Information, New York.

Universal Hak Asasi Manusia 1948

Yosep Adi Prasetyo, "Hak Ekosob dan Kewajiban Negara", Pemerkuatan Hak Asasi Manusia Untuk Hakim Seluruh Indonesia, Holiday Resort Lombok, 2831 Mei 2012. 